\title{
THE PRESENT STATUS OF BAZZANIA CURVIDENS STEPH. (LEPIDOZIACEAE)
}

\section{Andrea Sass-Gyarmati ${ }^{*}$ \& Catherine Reeb ${ }^{2}$}

\author{
${ }^{1}$ Institute of Biology, Eszterházy Károly University, P. O. Box. 43, H-3301 Eger, \\ Hungary; Institut de Systématique Evolution Biodiversité, Sorbonne Université, \\ Muséum National d' Histoire Naturelle, CNRS, EPHE, 57 rue Cuvier 75005 Paris, \\ France; *E-mail: sassgyarmati@gmail.com
}

\begin{abstract}
Based on study of the types and additional specimens of the Madagascan Bazzania curvidens Steph. is proposed to be included as a subspecies under Bazzania decrescens (Lehm. et Lindb.) Trevis.
\end{abstract}

Keywords: Bazzania, Madagascar, Lepidoziaceae

We studied various Madagascan collections of Bazzania decrescens (Lehm. et Lindb.) Trevis. specimens with recurved lobe teeth and revealed their identity with Bazzania curvidens Steph., described from Madagascar (Stephani 1891). S. Arnell (1965) considered $B$. curvidens to probably only be a form of Bazzania decrescens. It was also referred by E. Jones (1975) and R. Grolle (1995) to the Bazzania decrescens complex. Then the taxon was collected in two parts of Madagascar by Pócs et al., Roger Heim (Plate II) Illustrations of Bazzania curvidens were published in Stephani's Icones (1985: fig. 7079, under Mastigobryum curvidens).

We examined three type specimens of Bazzania curvidens Steph. (holotype preserved in Geneva Herbarium G15409! and isotypes in PC herbarium PC0101769!, PC0101770!), all collected in Madagascar, in sylva Alakatz by Perrot in 1891 (Plate I).

This study confirmed the recognition of Bazzania curvidens as a taxon subordinate to Bazzania decrescens instead of considering them as two different species. Bazzania curvidens differs from the Bazzania decrescens only by the incurved leaf and underleaf teeth and fits well in the original descriptions of Stephani "cum Bazzania 
decrescente comparanda...optima distincta dentibus numerosis in apice foliorum varieque incurvis." The present known distribution of the subspecies is restricted to Madagascar, we therefore consider the rank of subspecies justifiable for it.
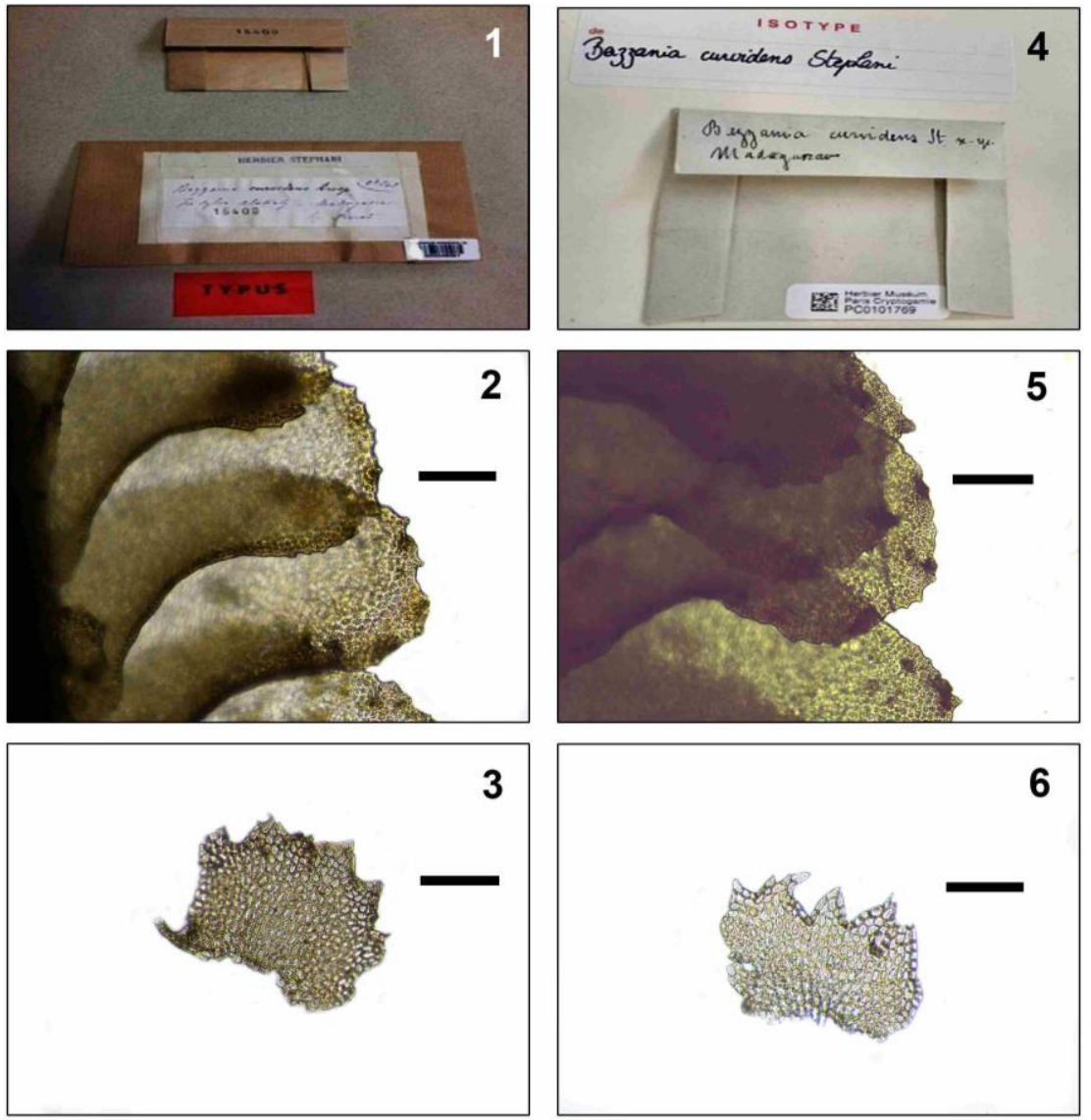

Plate I. Figures 1-3. Specimen kept in the Stephani herbarium, as type of Bazzania curvidens Steph. (Perrot, G15409!) Figs. 2-3: leaf and underleaf apices showing incurved teeth Figures 4-6. Specimen kept in the PC herbarium, as isotype of Bazzania curvidens Steph. (Perrot, PC0101769!) Figures 5-6. leaf and underleaf apices showing incurved teeth. The scale bar in all cases $200 \mu \mathrm{m}$ long. 

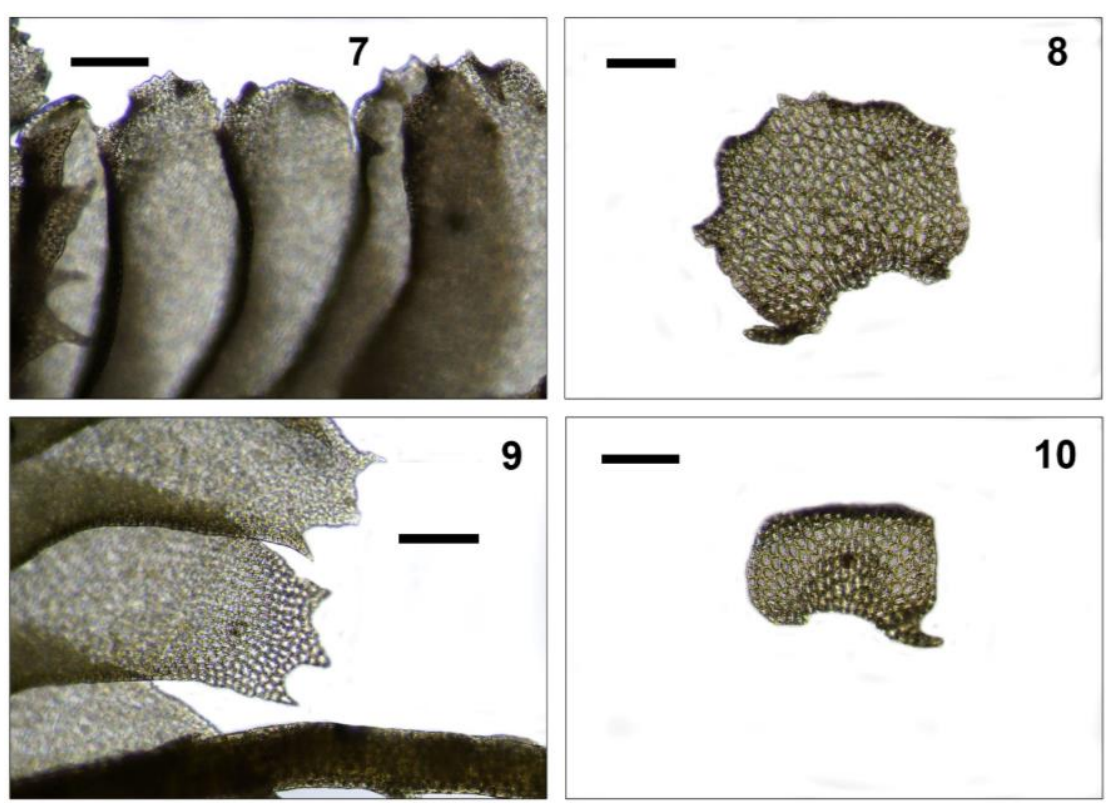

Plate II. Figures 7-8. Bazzania decrescens (Lehm. et Lindenb.) Trevis. ssp. curvidens (Steph.) Gyarmati Figs. 7: leaf margin and 8: underleaf, Madagascar. Forêt d'Amoapaka. 8.09.1934. R. Heim 1126 (PC) Figures 9-10. Bazzania decrescens (Lehm. et Lindb.) Trevis. ssp. decrescens Figs. 9: leaf margin and 10: underleaf, Madagascar. TOAMASINA Province. Park National de Mantadia. 2.10.2018. Sass-Gyarmati 1804/A (EGR). The scale bar in all cases $200 \mu \mathrm{m}$ long.

\section{FORMAL TREATMENT}

The format follows Söderström et al. (2012).

Bazzania decrescens (Lehm. et Lindenb.) Trevis. ssp. curvidens (Steph.) Gyarmati comb. et stat. nov.

Basionym: Bazzania curvidens Steph., Bull. Soc. Roy. Bot. Belgique, Compt. Rend. 30 (2): 197, 1891 (Stephani 1891).

$\equiv$ Mastigobryum curvidens (Steph.) Steph., Spec. Hepat. 3: 480 (Stephani 1908)

Type: Madagascar, in sylva Alakatz. Perrot 1891. (holotype G15409!; isotypes PC0101769!, PC0101770!) 
Additional specimens seen: Bazzania decrescens (Lehm. et Lindenb.) Trevis. ssp. curvidens (Steph.) Gyarmati. Madagascar. Forêt d'Amboapaka. Sur tronc pourri. 9.09.1934, R. Heim. no. 1128a (PC).

Angavo Escarpment. Old Eucalyptus plantation replacing montane rainforest at the $S$ side of main road between Ambatolaona and Mandraka. S.\& T. Pócs and A. Szabó, 10 \& 27. August 1998. no. 9868 (EGR).

Acknowledgements - We sincerely thank GBIF-BID and the European Union for funding the BRYOTAN project (AF2017-0174-NAC). We are also thankful to the careful reviewers, Anders Hagborg (Chicago, Field Museum) and to Tamás Pócs (Eger, Eszterházy Károly University) for their useful advises and corrections.

\section{REFERENCES}

Arnell, S. (1965). Hepaticae collected by Mr. Gillis Een in Mauritius and Réunion in 1962. Svensk Botanisk Tidskrift 59: 65-69.

Grolle, R. (1995). The Hepaticae and Anthocerotae of the East African Islands. An annotated catalogue. Bryophytorum Bibliotheca 48: 1-178.

JonEs, E.W. (1975). African Hepatics. XXVII. Bazzania. Journal of Bryology 8: 299316.

Söderström, L., HagborG, A. \& von Konrat, M. (2012). Notes on Early land Plants Today. Phytotaxa 65: 41-42. https://doi.org/10.11646/phytotaxa.65.1.5

Stephani, F. (1891). Hepaticae. In: Renauld, F. \& CARdot, J. (eds.): Musci exotici novi vel minus cogniti. II. Bulletin de la Société Royale de Botanique de Belgique, Comptes-rendus des Séances 30 (2): 181-207.

STEPHANI, F. (1985). Icones Hepaticarum. Microfiche ed. IDC, Leiden.

(submitted: 07.04.2021, accepted: 22.04.2021) 